Sains Malaysiana 48(8)(2019): 1671-1683

http://dx.doi.org/10.17576/jsm-2019-4808-13

\title{
The Effect of Stichopus chloronotus Aqueous Extract on Human Osteoarthritis Articular Chondrocytes in Three-Dimensional Collagen Type I Hydrogel in vitro
}

(Kesan Ekstrak Akues Stichopus chloronotus pada Kondrosit Osteoartritis Artikul Manusia dalam Kolagen Tiga Dimensi Hidrogel Jenis I secara in vitro)

\author{
Mohd Heikal Mohd Yunus*, Ahmad NazRun Shuid, Mohd Fauzi Busra, Chua Kien Hui, \\ NORZANA ABDUL GHAFAR \& RIZAL ABD RANI
}

\begin{abstract}
Autologous chondrocyte-seeded scaffolds have proved to be one of the most promising alternative therapies for articular cartilage defects. However, the chondrocytes have specific nutritional requirements and risk of dedifferentiation during in vitro expansion. Stichopus chloronotus aqueous extract (SCAE) was investigated as a medium supplement for threedimensional (3D) collagen type I hydrogel scaffold seeded with chondrocytes to determine whether SCAE is capable of maintaining phenotype and sustaining extracellular matrix synthesis and deposition. Human osteoarthritis articular chondrocytes were isolated from the knee joint cartilage of patients underwent total knee replacement surgery. Human osteoarthritis articular chondrocytes were encapsulated in collagen type I hydrogel and cultured in basic medium with $0,0.1$ and $0.2 \%$ of SCAE. The chondrocytes in 3D culture were evaluated by means cell morphology and proliferation, quantitative phenotypic expression of collagen type I, II, aggrecan core protein and sox-9. H\&E, toluidine blue staining and sulfated glycosaminoglycan (SGAG) production were analyzed after 7 days in culture. Chondrocytes cultured in $3 D$ with various SCAE concentration appeared with polygonal morphology maintaining their chondrocytes characteristic. SCAE supplementation promoted chondrocytes proliferation and the ability of the cells to express gene encoding collagen type I decreased, whereas their ability to express collagen type II, aggrecan core protein and sox 9 increased as compared to control. The cartilaginous matrices were positively stained toluidine blue concomitant with higher sGAG accumulation in SCAE-supplemented culture medium. This study shown that SCAE may be beneficial for in vitro development of $3 D$ chondrocytes culture for use in cartilage tissue engineering therapies.
\end{abstract}

Keywords: Chondrocytes; collagen Type I; osteoarthritis; Stichopus chloronotus; three dimensional culture

\section{ABSTRAK}

Biobahan yang disemai kondrosit secara autologus telah terbukti menjadi salah satu terapi alternatif yang paling berkesan untuk kecacatan rawan artikul. Walau bagaimanapun, kondrosit mempunyai keperluan nutrien tertentu dan berisiko untuk mengalami nyahpembezaan semasa pengembangan in vitro. Ekstrak air Stichopus chloronotus (SCAE) telah dikaji sebagai tambahan bagi media untuk kondrosit yang disemai dalam hidrogel kolagen jenis I secara tiga dimensi (3-D) untuk menentukan sama ada SCAE mampu mengekalkan fenotip dan sintesis serta pemendapan matriks ekstrasel. Kondrosit osteoartritis manusia dipencilkan daripada rawan sendi lutut pesakit yang menjalani pembedahan penggantian lutut secara total. Kondrosit osteoartritis manusia disemai dalam hidrogel kolagen jenis I dan dikultur dalam medium asas dengan 0, 0.1 dan 0.2\% SCAE. Kondrosit yang dikultur secara 3D dinilai daripada segi morfologi dan percambahan sel, ekspresi fenotip kuantitatif bagi kolagen jenis I, II, protein teras agrekan dan sox-9. Pewarnaan $H \& E$ dan toluidin biru serta penghasilan glikosaminoglikan tersulfat (sGAG) dianalisis selepas dikultur selama 7 hari. Kondrosit yang dikultur secara 3D dengan pelbagai kepekatan SCAE menunjukkan morfologi poligonal mengekalkan ciri-ciri kondrosit. Penambahan SCAE meningkatkan percambahan kondrosit dan keupayaan sel untuk mengekspresi gen pengekod kolagen jenis I menurun, sedangkan keupayaan untuk mengekspresikan gen kolagen jenis II, protein teras agrekan dan sox 9 meningkat berbanding dengan kawalan. Matriks ekstrasel diwarnakan positifoleh toluidin biru, setara dengan pengumpulan sGAG yang lebih tinggi dalam media kultur dengan penambahan SCAE. Kajian ini memperlihatkan bahawa SCAE boleh memberi manfaat dalam pembentukan kultur kondrosit 3D secara in vitro untuk digunakan dalam terapi kejuruteraan tisu rawan.

Kata kunci: Kolagen jenis I; kondrosit; kultur tiga dimensi; osteoarthritis; Stichopus chloronotus

\section{INTRODUCTION}

Human articular cartilage lines the ends of long bones and functions typically to provide a low-friction, load-bearing surface for efficient joint articulation. This dense, avascular tissue consists of sparsely embedded chondrocytes in an organic matrix primarily consisting of collagen type 
II and proteoglycan, which is continually maintained and remodelled by the chondrocytes (Chen et al. 2004). Articular chondrocytes play a major role in maintaining the integrity of the cartilage through the control of anabolic and catabolic activities. Although this tissue normally functions well over a lifetime of use, damage resulting from disease processes or trauma, interrupts tissue structure and function, precipitating progressive damage resulting in joint degeneration or osteoarthritis. It possesses a limited capacity for intrinsic repair or regeneration because of its dense composition and scant vascularity after skeletal maturation (Byers et al. 2008; Mahapatra et al. 2016). A collective of surgical and cell-based regenerative strategies have been developed in attempts to repair articular cartilage defects, however it frequently results in the development of fibrous tissue that is rich in collagen type I, and lacking the mechanical properties and zonal organization of normal articular cartilage (Levett et al. 2013). A cellbased tissue engineering technique including autologous chondrocyte implantation ( $\mathrm{ACI}$ ) has proven to be one of the most promising alternative therapies for articular cartilage defects. However, through long term study, some of the grafted chondrocytes isolated from patient of the same osteoarthritic knee eventually differentiate into fibrocartilage (Nurzazlin et al. 2018).

One of the issues when expanding the autologous chondrocytes is to overcome the risk of dedifferentiation that occurs during in vitro expansion. Chondrocytes dedifferentiation is primarily observed by the morphological change towards fibroblast-like structure, loss of collagen type II and proteoglycans, and producing of more collagen type I (Jeyakumar et al. 2017). Furthermore, the availability of healthy autologous cartilage and the restricted proliferative potential of the chondrocytes, which appears to decrease with age, are the other limitations that should be addressed. Interestingly, the dedifferentiation is reversible either by selection of appropriate bioactive or signalling molecules or culturing in 3-dimensional environment such as hydrogels or intact polymer matrices, supporting the chondrocytes to recover their phenotype (Kontturi et al. 2014; Levett et al. 2013).

The selection of biomaterial is essential depending on its specific tissue structure and application. A biomaterial should consist of basic criteria that are biocompatible, biofunctional, bioactive, less or no immune response, bioactive, bioinert and can be sterilised. The sterilisation process is necessary to avoid any chance of infection after implantation and should not change its original 3D-conformation structure prior to the loss of its native properties. Briefly, biocompatibility is emphasized on the tolerance of the human body to accept or interact with the implanted biomaterial. Furthermore, biofunctionality of any implanted biomaterials is required to perform its function as its designed for, within a period of time after implantation effectively. Biodegradable property is commonly depending on the application which requires a certain period of time to be degraded, solubilised or absorbed after in contact with the human body (Fauzi et al. 2016). The rheology of biomaterial design is another determining factor that to be rigid self-sustainability as a scaffold for further support of cell growth, as well as an appropriate stiffness that is important to maintain cell phenotype, adhesion and gene expression (Yan \& Pochan 2010).

An optimal biomaterial should degrade in a controlled manner without causing cytotoxicity, and it should promote cell viability, chondrocytic phenotype, and extracellular matrix production which resembling the original hyaline cartilage that rich in collagen type II and aggrecan. Hydrogels are a class of biomaterials that provide numerous advantages, including high tissue-like water content, efficient nutrient and waste transport, and the ability to effectively and uniformly encapsulate cells (Park et al. 2011). Some classic examples of naturally derived hydrogels are collagen type I, gelatin, agarose, fibrin and alginate. These materials have been shown to improve the cell survivability and maintenance of cellular phenotype (Klein et al. 2010). They have been used in clinical trials for the repair of large cartilage defects without problems although, there is potential for immune rejection. Collagen is an attractive material for biomedical applications as it is the most abundant protein in mammalian tissues and is the main component of natural extracellular matrix (Drury et al. 2003). Collagen type I is frequently used as hydrogel for cartilage engineering due to its excellent biocompatibility and biodegradability, low immunogenicity and it mimics the natural microenvironment allowing homogeneous cell distribution and deposition of extracellular matrix (Chowdhury et al. 2018; Fauzi et al. 2016,). Although collagen type I is not typically associated with chondrogenesis, it has been previously shown that bovine and human chondrocytes can remodel collagen type I into more suitable extracellular matrix components (Callahan et al. 2012). Previous studies showed that chondrocytes embedded in collagen type I was able to maintain a round morphology and express important cartilage molecules such as collagen type II and proteoglycans (Klein et al. 2010). The collagen type I based scaffold have the potential for the development of in vitro tissue models to understand normal and diseased tissue biology and drug discovery, and the use of the scaffold as a vehicle for cells, drugs and bioactive compounds (Chowdhury et al. 2018).

During in vitro maintenance of chondrocyteseeded constructs, the culture medium was frequently supplemented with animal serum to enhance cellular activities such as extracellular matrix synthesis and cell proliferation. The effects of serum that obtained from a bovine foetal source have been well characterised for chondrocyte culture. The chondrocyte-seeded constructs cultured in a serum-supplemented medium have been found to induce cell division and extracellular matrix synthesis and retention for up to several weeks in a variety of scaffolds. Although serum-supplemented culture medium has proven sufficient for in vitro studies, the use of animal serum may not be ideal for cartilage tissue-engineering 
therapies because of the potential risk of exposure to biological pathogens related to animal-derived materials. Furthermore, it will result in excessive cell proliferation or chondrocyte phenotypic instability thus, preventing a clear understanding of the cellular response (Kisiday et al. 2005; Zhang et al. 2009). Several studies have shown that serum-free formulations with the use of medium supplemented with bioactive or signalling molecules such as insulin, transferrin, and selenium (ITS) for in vitro studies concerning cartilage explants and chondrocyte expansion would overcome the regulatory barriers (Zhang et al. 2009).

The species of sea cucumbers derived mainly from two families, Holothuriidae and Stichopodidae have been recorded from the coral reef areas in Peninsular Malaysia and Sabah in which 20 subspecies are commercially important (Choo 2008). Both these species are used in the preparation of traditional medicinal products and less commonly used as food items. Stichopus chloronotus extract contains fatty acids profile in terms of arachidonic, eicosapentaenoic (EPA) and docosahexaenoic acid (DHA) which are known as n-3 PUFAs, and phenolic compounds known to affect several pharmacological and biochemical pathways in addition to their strong anti-oxidation and antiinflammatory properties (Althunibat et al. 2009; Fredalina et al. 1999). Our previous study on the effect of Stichopus chloronotus aqueous extract (SCAE) on monolayer human osteoarthritic articular chondrocytes showed that SCAE could effectively promote the proliferation of chondrocytes and enhance secretion and synthesis of the cartilage extracellular matrix. It could prevent chondrocyte dedifferentiation by up-regulating the expression levels of the collagen II, sox 9 and aggrecan core protein genes while down-regulating the expression of collagen type I (Mohd Yunus et al. 2019).

Therefore, in this study, SCAE was investigated as a medium supplement for three-dimensional (3-D) collagen type I hydrogel scaffold seeded with chondrocytes to determine whether SCAE-supplemented medium is capable of maintaining phenotype and sustaining extracellular matrix synthesis and deposition. These studies were conducted with human osteoarthritis articular chondrocytes, a cell source frequently used for cartilage tissue-engineering studies encapsulated in collagen type I hydrogels. We investigated chondrocyte morphology, biochemical assay, semi quantitative reverse transcriptasepolymerase chain reaction (RT-PCR) and histological examination within the hydrogels post culture to evaluate the potential of SCAE.

\section{MATERIALS AND METHODS}

\section{HUMAN ARTICULAR CHONDROCYTES} ISOLATION AND CULTURE

Prior ethical approval was obtained from the Research and Ethical Committee of Faculty of Medicine, Universiti Kebangsaan Malaysia (FF-2015-235). All the human study subjects provided informed consent.
Human articular cartilage was obtained from six consented patient aged between 55-70 years old that underwent total knee arthroplasty (TKR). All patients were diagnosed to have knee osteoarthritis with lesion scored grade 4 according to the International Cartilage Repair Society (ICRS) in which there was severe cartilage lesion and the defect penetrated the subchondral bone. The cartilage was harvested from the medial and lateral condyle of the distal femur. All samples were processed within $24 \mathrm{~h}$ following surgery.

Specimens were washed with phosphate-buffered saline (PBS; pH7.2, Gibco, Grand Island, NY) containing $100 \mathrm{U} / \mathrm{mL}$ penicillin. Each sample was minced into 1 $\mathrm{mm}^{3}$ fragments and digested with $0.6 \%$ Collagenase II (Gibco) in an orbital incubator (Stuart Scientific, Redhill, UK) at $37^{\circ} \mathrm{C}$ for $6-8 \mathrm{~h}$. After digestion, the cell suspension was centrifuged and the cell pellet were then cultured in chondrocytes growth medium consist of Ham's F-12:Dulbecco's Modified Eagles's Medium (Gibco), $10 \%$ foetal bovine serum (FBS, Gibco) $1 \%$ of antibiotic and antimycotic (Gibco), $1 \%$ of $50 \mu \mathrm{g} / \mathrm{mL}$ ascorbic acid (Sigma-Aldrich), 1\% $200 \mathrm{mM}$ L-glutamine (Gibco) and $15 \mathrm{mM}$ herpes buffer (Gibco) in T25 culture flasks (Nunc, Denmark). Primary cultured chondrocytes were maintained in a humidified atmosphere of $5 \% \mathrm{CO}_{2}$ incubators at $37^{\circ} \mathrm{C}$. The culture media were changed every other day. Once the cultured cells were $80 \%$ confluence, the chondrocytes were trypsinized using $0.05 \%$ Trypsin-EDTA (Gibco). The resulting cell suspension was centrifuged at $5000 \mathrm{rpm}$ for $5 \mathrm{~min}$ and the number of viable cells was determined with a hemocytometer using trypan blue staining.

\section{THREE DIMENSIONAL (3D) TISSUE ENGINEERED CONSTRUCT}

The $3 \mathrm{D}$ in vitro tissue engineered construct is designed based on seeding the cultured OA chondrocytes in ovine collagen hydrogel at a density of about $1 \times 10^{6}$ cells $/ \mathrm{mL}$. The dried ovine collagen was dissolved in the $0.35 \mathrm{M}$ acetic acid to a final concentration of $14.25 \mathrm{mg} / \mathrm{mL}$ for $24-48 \mathrm{~h}$ at $4{ }^{\circ} \mathrm{C}$. To fabricate hydrogel, the ovine collagen solution was neutralized using $1 \mathrm{M}$ sodium hydroxide (Sigma) until pH7.0 before gelation and incubated at $37^{\circ} \mathrm{C}$ for 2 h. The isolated primary cultured OA chondrocytes were suspended in ovine collagen hydrogel solution. A $500 \mu \mathrm{L}$ OA chondrocytes hydrogel suspension which contained 250 thousand cells, was then pipette in each well of 24-well plates and was incubated for $1 \mathrm{~h}$ in a humidified atmosphere of $5 \% \mathrm{CO}_{2}$ incubator at $37^{\circ} \mathrm{C}$ to allow collagen gelation. Thereafter, serum free medium, Ham's F-12:Dulbecco's Modified Eagles Medium (FD) with $0.1 \%$ and $0.2 \%$ SCAE supplementation was added to the $3 \mathrm{D}$ construct and culture medium without SCAE supplementation was served as a control. The culture plate was maintained in a humidified atmosphere of $5 \% \mathrm{CO}_{2}$ incubator at $37^{\circ} \mathrm{C}$ for 7 days. Culture medium was changed every other day and culture supernatant was pooled in a $50 \mathrm{~mL}$ tube and stored at $-80^{\circ} \mathrm{C}$ until further use. Morphological analysis of chondrocytes 
was routinely performed using an inverted phase-contrast microscope (Olympus,Tokyo) and photographed. Cell viability and proliferation rate for each sample was evaluated following 7 days of culture.

In order to evaluate the cell number within the collagen hydrogels, cells were recovered at day 7 by collagenase digestion. Collagen hydrogels from three groups of culture were minced into small pieces and incubated in $0.6 \%$ Collagenase II (Gibco) in an orbital incubator (Stuart Scientific, Redhill, UK) at $37^{\circ} \mathrm{C}$. As soon as the gels were completely solubilised, the cell suspension was centrifuged at $5000 \mathrm{rpm}$ for $5 \mathrm{~min}$ and the number of viable cells was determined with a hemocytometer using trypan blue staining. The diameters of chondrocytes-seeded collagen hydrogel were measured at day 7 post seeding. The chondrocyte-mediated contraction was determined by subtracting the percentage contraction of collagen hydrogel that cultured in all types of culture medium from the actual size of collagen hydrogel.

PREPARATION OF Sticophus chloronotus AQUEOUS EXTRACT

Sticophus chloronotus (SC) were freshly harvested from Pulau Bidong, Terengganu, Malaysia. Identification of species was based on the method described by Forbes et al. (1999) and confirmed by a marine expert from University Malaysia Terengganu. The extracts were prepared according to Fredalina et al. (1999) with slight modification. The dried product from the extraction process was transformed into water extract for cell culturing purposes using sterile phosphate-buffered saline (PBS; pH7.2, Gibco Grand Island, NY)). The extract was filtered using $0.2 \mu \mathrm{m}$ syringe filter into a $50 \mathrm{~mL}$ sterile tube and stored at $4^{\circ} \mathrm{C}$ until further use.

\section{TOTAL RNA EXTRACTION}

Total RNA from cultured chondrocytes was extracted to build up changes in gene expression profile. Approximately $1.0 \times 10^{6}$ chondrocytes cultured with or without supplementation of SCAE were harvested via trypsinization and counted using haemocytometer. The isolated chondrocytes then centrifuged at $5000 \mathrm{rpm}$ for 5 min at $37^{\circ} \mathrm{C}$. The chondrocyte pellet was suspended and purification of total RNA was performed using the RNeasy kit (Qiagen Inc., Valencia, CA). The yield and purity of isolated RNA was determined by using an Infinite 200 PRO NanoQuant spectrophotometer (Tecan, Austria GmbH) measured at $260 \mathrm{~nm}$. Total RNA was stored at $-80^{\circ} \mathrm{C}$ immediately after extraction.

\section{cDNA SYNTHESIS}

Complementary DNA was synthesized from standardized total RNA from each treatment group (cultured chondrocytes with or without SCAE supplementation) using iScript ${ }^{\mathrm{TM}}$ reverse transcription (Biorad). The reaction was carried out according to the protocol recommended by the manufacturer.

\section{REAL TIME REVERSE TRANSCRIPTASE-POLYMERASE CHAIN REACTION (qRT-PCR)}

The expression of cartilage anabolic markers; Collagen I, Collagen II, Sox9 and Aggrecan core protein were evaluated by quantitative real-time PCR protocol (SsoAdvanced $^{\mathrm{TM}}$ Universal SYBR ${ }^{\circledR}$ Green Supermix, BIO-RAD). The sequences of the both forward and reverse primers were designed based on the sequences published in GenBank using primer-3 software (Table 1). Human GAPDH gene was used as housekeeping gene. The quantitative RT-PCR protocol was performed in Bio-Rad iCycler set for 40 cycles for each run. The data were analyzed using Bio-Rad iCycler software. For gene expression quantitation, the $\mathrm{Ct}$ values of the gene of interest were normalized to GAPDH. The relative mRNA expression of the target gene was calculated with the following equation: 2 (Ct GAPDH-Ct target gene).

\section{SULPHATED GLYCOSAMINOGLYCAN (SGAG) ASSAY}

The amount of SGAG released into the medium of all culture supernatant with or without SCAE supplementation was measured spectrophotometrically by using Blyscan assay kit (Biocolor, Carrickfergus, Northern Ireland), according

TABLE 1. List of primers used in RTPCR for chondrogenic genes

\begin{tabular}{|c|c|c|c|}
\hline Primer & Accession No. & Primer Sequence $5^{\prime}-3^{\prime}$ & Product size PCR (bp) \\
\hline COL-1 & NM_000088 & $\begin{array}{l}\text { F: } 5^{\prime}-\text { agg gct cca acg aga tcg aga- } 3^{\prime} \\
\text { R: } 5^{\prime} \text {-tac agg aag cag aca ggg cca- } 3^{\prime}\end{array}$ & 222 \\
\hline COL-2 & NM_001844 & $\begin{array}{l}\text { F: } 5^{\prime} \text {-cta tct gga cga agc agc tgg ca- } 3^{\prime} \\
\text { R: } 5^{\prime} \text {-atg agg aag cag aca ggg cca-3' }\end{array}$ & 209 \\
\hline sox 9 & NM_000346 & $\begin{array}{l}F: 5^{\prime}-\mathrm{cac} \text { tgt tac cgc cac ttc cc--3' } \\
\text { R: } 5^{\prime} \text {-acc agc gga agt cec ctt cg-3 }\end{array}$ & 236 \\
\hline $\mathrm{ACP}$ & NM_001135 & $\begin{array}{l}\text { F: } 5^{\prime} \text {-gcg gag gaa gtc ggt gaa ga- } 3^{\prime} \\
\text { R: } 5^{\prime} \text {-cce tct cgc ttc agg tca gc- } 3^{\prime}\end{array}$ & 183 \\
\hline GAPDH & NM_002046 & $\begin{array}{l}\text { F: } 5^{\prime}-\text { tcc ctg agc tga acg gga ag- } 3^{\prime} \\
\text { R: } 5^{\prime} \text {-gga gga gtg ggt gtc get gt-3' }\end{array}$ & 217 \\
\hline
\end{tabular}

(Source: www.ncbi.nlm.nih.gov/nucleotide) 
to the manufacturer's protocol. The GAG content in each type of culture medium was determined by a standard curve drawn using standard solutions containing bovine tracheal chondroitin 4-sulfate. The sGAG absorbance was determined using ELISA microplate reader at $620 \mathrm{~nm}$ wavelength.

\section{HISTOLOGICAL ANALYSIS}

The fresh $3 \mathrm{D}$ tissue engineered construct post culture was mounted directly onto a specimen holder with cryocompound frozen and placed on the freezing shelf of the cryostat to stabilise at chamber temperature. The specimen holder is clamped firmly onto the object head mounted on the spindle of the microtome and cut into 4 um thick sections (Leica, Nussloch, Germany) then placed onto glass slides. The sections of fresh frozen tissue were fixed immediately with $70 \%$ alcohol and then thoroughly rinsed in water to make sure the section was hydrated so that aqueous reagents can easily penetrate the cells and tissue elements.

\section{HAEMATOXYLIN AND EOSIN STAINING}

The slides were stained with haematoxylin solution for 8 min and then rinsed with tap water and treat with a weak alkaline solution ( $1 \%$ ammonium solution). The sectioned then rinsed again with tap water before counterstained with eosin solution for $1 \mathrm{~min}$. The dehydration process was performed with 80, 90 and 100\% alcohol before being dipped into xylene to clear the tissue and rendered its completely transparent. A thin layer of the mounting solution was applied on the sectioned before placing the glass cover slip for microscopic examination to assess the construct morphology.

\section{TOLUIDINE BLUE STAINING}

Toluidine blue staining was performed as followed. $0.04 \%$ Toluidine blue stain was prepared by mixing $0.04 \mathrm{gm}$ toluidine blue into $100 \mathrm{~mL} 0.2 \mathrm{M}$ acetate buffer solution ( $\mathrm{pH} 3.75-4.25)$. The slides then were stained with $0.04 \%$ toluidine blue for $10 \mathrm{~min}$ and rinsed with tap water before hydration with 80,90 and $100 \%$ alcohol to remove traces of water before being dipped into xylene. Finally, the slides were mounted using DPX before the glass cover slip placement for microscopic examination to detect extracellular matrix and proteoglycans formation.

\section{STATISTICAL ANALYSIS}

The data have been analysed using the GraphPad Prism version 7.0 device (GraphPad Software, Inc., USA). The data collected from various quantitative parameters were presented as the mean \pm standard error of mean (SEM) of the sample size. Data comparisons between each control and treated group were conducted using one-way ANOVA with significant value at $p<0.05$.

\section{RESULTS}

\section{CELL BEHAVIORS AND MORPHOLOGY}

A homogeneous distribution of the OA chondrocytes could be seen within collagen hydrogel constructs that cultured with FD with SCAE $0.1 \%$ and $0.2 \%$ supplementation. The chondrocytes retained polygonal morphology and were isolated in lacunae similar to the chondrocytes in native cartilage and remaining fixed in the constructs (Figure 1). The cell population was substantially increased, and polygonal aggregates of chondrocytes were profoundly observed in collagen hydrogel cultured with FD with $0.1 \%$ and $0.2 \%$ SCAE. The presence of cell agglomerates showed active cell division of OA chondrocytes within all constructs similarly to isogen groups of the newly-formed hyaline cartilage. The high cellularity and the contraction of the construct were observed by microscopy after 7 days. The collagen hydrogels exposed to FD with $0.2 \%$ SCAE supplementation medium demonstrated the highest contraction, resulting in curled edges and an opaque, dense structure (Figure 2). The contraction was restricted to the vertical dimension alone, giving the construct a meniscoid form in culture. The collagen hydrogels cultivated in medium containing $0.1 \%$ and $0.2 \%$ SCAE had contracted to $79.9 \pm 32.6 \%$ and $72 \pm 29.4 \%$ of their original diameters, respectively. The contraction of construct, increased with increasing concentrations of SCAE in the culture medium with significant differences $(p<0.05)$ (Figure 2$)$. In contrast, minimal contraction was observed in collagen hydrogels cultured in FD only which retained their translucent gel appearance. The decreases in collagen hydrogel sizes were less pronounced and were determined to $90.5 \pm 36.9 \%$ of their original diameters. The enhanced collagen hydrogel contraction was observed with increasing cell densities over 7 days of culture, especially the collagen hydrogels that culture in FD with supplementation of SCAE.

\section{CELL PROLIFERATION}

After 7 days, more than $90 \%$ of all OA chondrocytes remained viable in collagen hydrogel constructs that cultured in FD with $0.1 \%$ and $0.2 \%$ SCAE supplementation, whereas the remaining chondrocytes was found to attached to the culture plate surface. There were differences in both cell population and distribution between the three groups, in which the number of cells after 7 days was greater for $\mathrm{OA}$ chondrocytes cultured in FD with $0.1 \%$ and $0.2 \%$ SCAE supplementation. The chondrocytes proliferated at 3.2-fold and 3.8-fold increases with $0.1 \%$ and $0.2 \%$ SCAE, respectively, as compared to only 1.3 -fold in the control medium. The proliferation of cells increased with increasing concentrations of SCAE with significant differences ( $p<0.05)$, greater than the constructs cultured in the control medium (Figure 3(A)). The population doubling time was 3 days in the medium with $0.2 \%$ SCAE, 4 days in the medium with $0.1 \%$ SCAE and 7 days in medium without supplementation (Figure 3(B)). The higher proliferation 

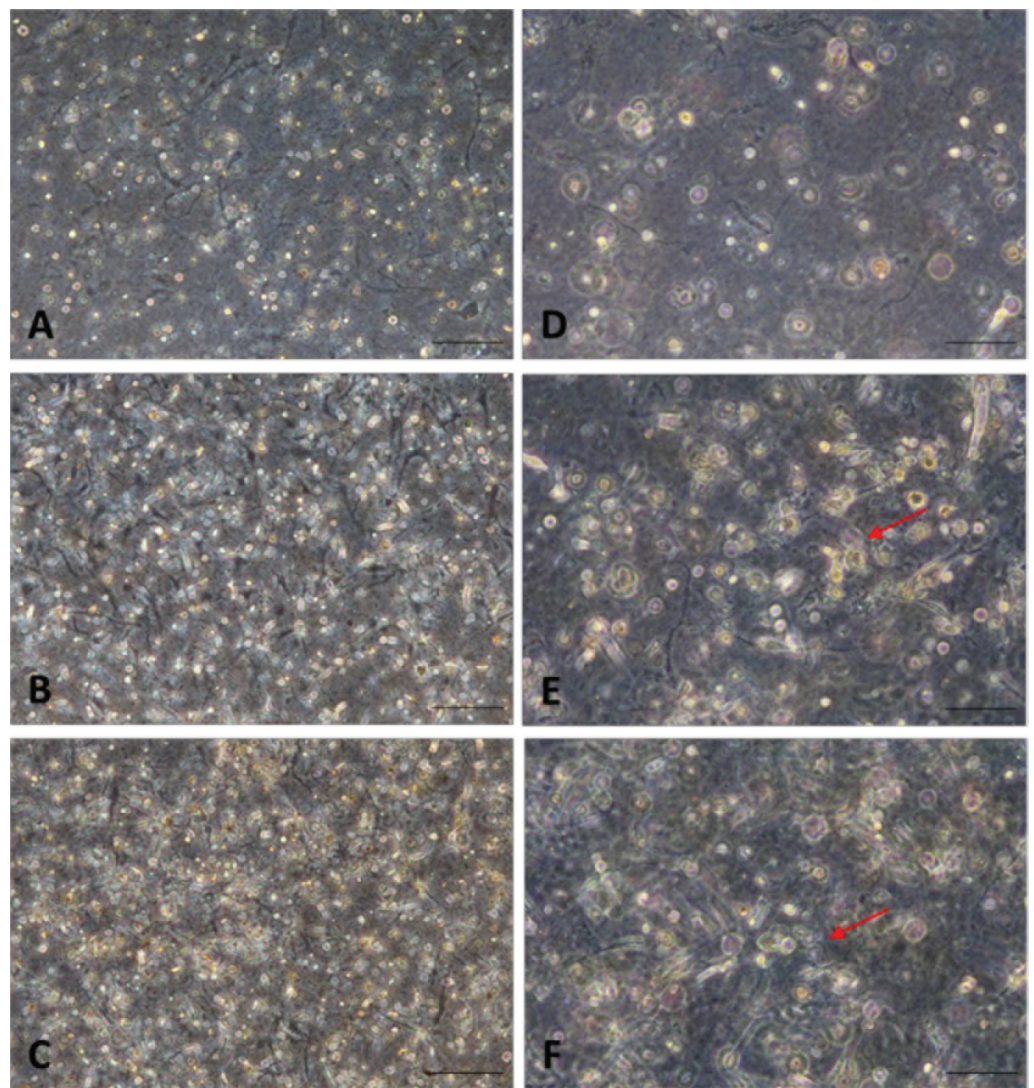

FIGURE 1. OA chondrocytes within the collagen type I hydrogel construct. After day-7 in vitro, the construct cultured in FD with $0.1 \%$ SCAE $(\mathrm{B}, \mathrm{E})$ and $0.2 \%$ SCAE $(\mathrm{C}, \mathrm{F})$ supplementation demonstrated polygonal aggregates of chondrocytes and increased cell density as compared to the chondrocytes cultured in control medium (FD only) (A,D). The chondrocytes retained polygonal morphology and isolated in lacunae. A-C magnification 4×, D-F magnification 10×. Bar=100 $\mu \mathrm{m}(\mathrm{A}, \mathrm{B}, \mathrm{C}), \mathrm{Bar}=50 \mu \mathrm{m}(\mathrm{D}, \mathrm{E}, \mathrm{F})$
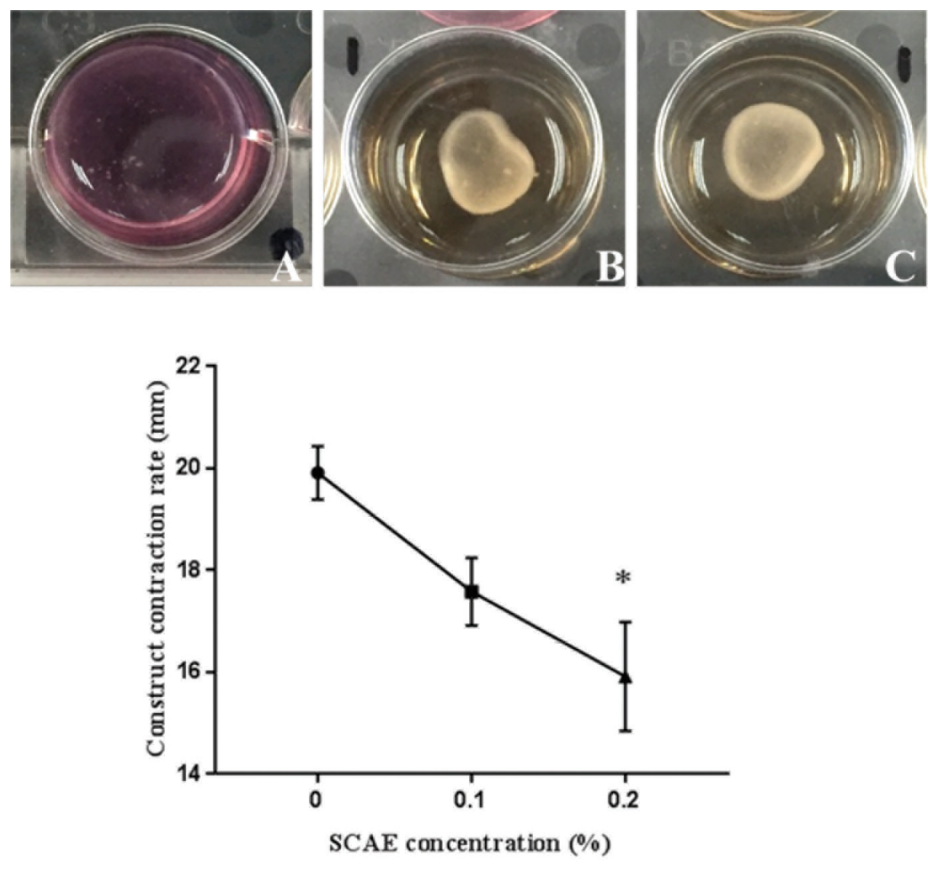

FIGURE 2. Collagen type I hydrogel construct cultured in FD medium with/without SCAE supplementation. The contraction of collagen hydrogels was observed after 7 days in culture. The collagen hydrogels exposed to FD with $0.1 \%$ and $0.2 \% \mathrm{SCAE}$ supplementation demonstrated the highest contraction as compared to the control medium, resulting in a curled edges and an opaque, dense structure 

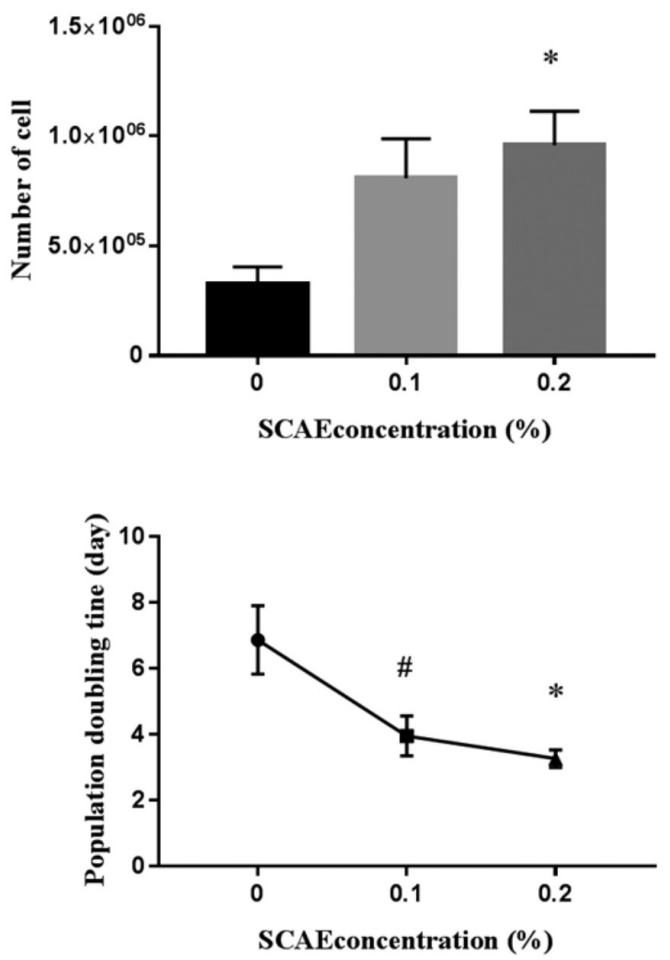

FIGURE 3. A and B shows growth kinetics of OA chondrocytes in collagen type I hydrogel cultured in FD medium with/without SCAE supplementation. (A) Cells proliferation rate in construct cultured in FD with $0.1 \%$ SCAE and $0.2 \%$ SCAE supplementation was significantly higher than control medium after 7 days. (B) The population doubling time was shortened to 3 days in medium with $0.2 \%$ SCAE, 4 days in medium with $0.1 \%$ SCAE as compared to 7 days in control medium: values were expressed as the mean $\pm \mathrm{SEM},(n=6)$ with $\# p<0.05$; compared values of control medium and FD with $0.1 \% \mathrm{SCAE},{ }^{*} p<0.05$; compared values of control medium and FD with $0.2 \%$ SCAE and $* * p<0.05$; compared values of FD with $0.1 \%$ SCAE and FD with $0.2 \%$ SCAE

rate of OA chondrocytes in the construct that cultured in the medium supplemented with SCAE had significantly shortened the population doubling time with the $p$-value at $<0.05$ as compared to OA chondrocytes cultured in the control medium. These results verified that the combination of SCAE in the medium was capable to support chondrocytes activity in the collagen hydrogel constructs.

\section{GENE EXPRESSION ANALYSIS}

Real-Time PCR was performed to determine the expression of chondrogenic differentiation genes; collagen type II, which is a cartilage-specific protein that accounts for $50 \%$ of all the proteins in the cartilage; sox 9 , which is a key transcription factor associated with chondrocyte differentiation; aggrecan core protein, which forms a major structural component of cartilage, particularly articular cartilage; and collagen type I, which is the most abundant collagen in the human body and is believed to be expressed in dedifferentiated chondrocytes. The collagen hydrogel cultured in the medium with SCAE supplementation demonstrated a significantly higher expression of chondrogenic genes (collagen type II, sox 9 and aggrecan core protein) as compared to collagen hydrogel cultured in the control medium (Figure 4). The collagen type II was expressed higher in the collagen hydrogel cultured in the medium with $0.1 \%$ and $0.2 \%$ $(p=0.04)$ SCAE supplementation as compared to the control culture medium, represented by 4 -fold and 6.7-fold increases, respectively. A similar statistically significant, up-regulation of gene expressions encoding the aggrecan core protein was observed for the collagen hydrogel incubated in the medium with $0.1 \%(p=0.04)$ and $0.2 \%$ ( $p=0.006)$ SCAE supplementation, differed by 6 -fold and 10 -fold decreases, respectively, as compared to control culture medium. The sox 9 expression was detected at low levels in all collagen hydrogel; however, the expression was found to be higher in $0.1 \%$ SCAE and $0.2 \% \mathrm{SCAE}$ supplementation as compared to control culture medium. The expression level of chondrogenic dedifferentiation gene, collagen type I was expressed higher and comparable in all types of culture medium. However, the chondrocytes phenotype index (ratio of collagen 11/collagen I) which represented the differentiation status of chondrocytes in collagen hydrogel was also increased by 4 -fold in the culture medium with $0.1 \%$ SCAE supplementation and 7 -fold in the culture medium with $0.2 \%$ SCAE supplementation. These results suggested that human OA chondrocytes encapsulated in the collagen hydrogel, cultured in the medium with SCAE enabled the maintenance of chondrocyte-like phenotype. 
COL I

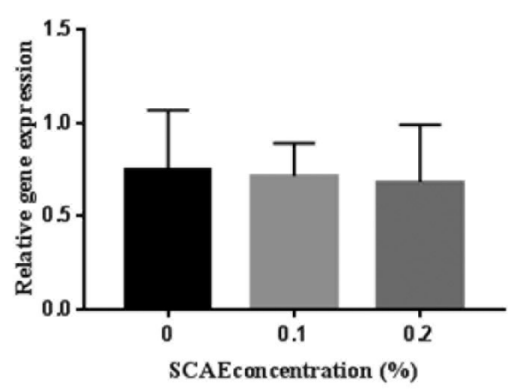

SOX 9

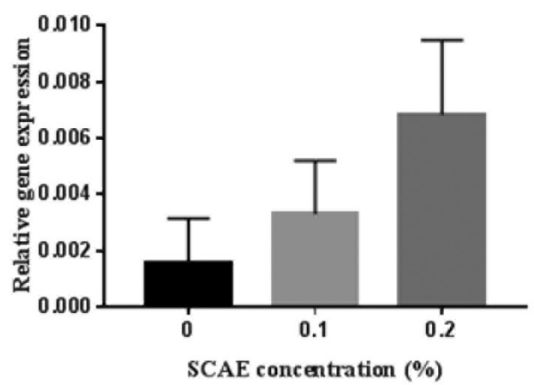

COL II

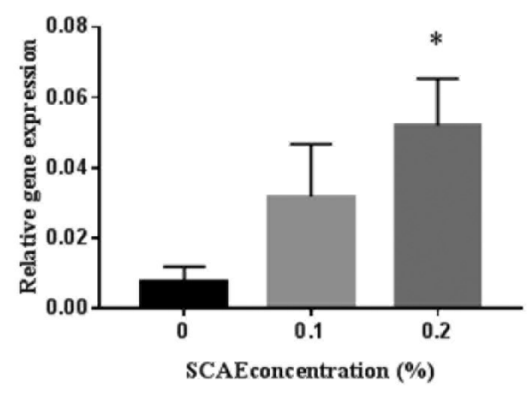

ACP

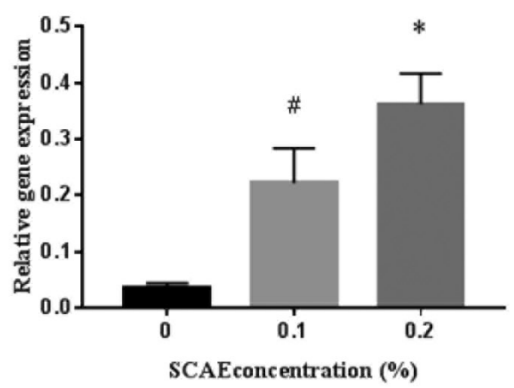

FIGURE 4. The expression of cartilage anabolic markers. Collagen I (COL1), Collagen II (COL2), Sox9 and Aggrecan core protein (ACP) genes expressions of human osteoarthritic articular chondrocytes in collagen type I hydrogel, cultured in FD medium with/without SCAE supplementation. A significantly higher expression of the Collagen II (COL2), Sox9 and Aggrecan core protein $(\mathrm{ACP})$ gene was observed in construct cultured with FD and $0.1 \%$ or $0.2 \%$ SCAE medium as compared with the control medium after 7 days of culture: Gene expression values were expressed as the mean $\pm \mathrm{SEM},(n=6)$ with $\# p<0.05$; compared values of control medium and FD with $0.1 \%$ SCAE, $* p<0.05$; compared values of control medium and FD with $0.2 \%$ SCAE and $* * p<0.05$; compared values of FD with $0.1 \%$ SCAE and FD with $0.2 \%$ SCAE

\section{SGAG ANALYSIS}

The total concentration of SGAG released in the medium of collagen hydrogel construct cultures, was measured through quantitative spectrophotometric analysis. The concentration of SGAG in the medium was substantially greater in the collagen hydrogel culture in FD with $0.1 \%$ SCAE and $0.2 \%$ SCAE supplementation than the construct cultured in the control medium at day 7 represented by 3.6fold and 5.8-fold increases in the amount of SGAG released compared with untreated controls with the differences being statistically significant in collagen hydrogel culture in FD with $0.2 \%$ SCAE supplementation with $p=0.02$ (Figure 5). Therefore, this study showed that SCAE supplementation could enhance proteoglycan production of chondrocytes.

\section{HISTOLOGICAL ANALYSIS}

The attachment and growth of OA chondrocytes in collagen hydrogel cultured under medium with various concentration of SCAE supplementation were observed by H\&E staining. The cells were found loosely dispersed in the constructs and showed signs of lacunae and cartilage isolated cells for the collagen hydrogel that cultured with all types of culture media. The chondrocytes maintained polygonal morphology and attached to the scaffold surface and penetrated into the scaffold interior through pores. The nuclei of chondrocytes were stained purplish blue by haematoxylin and matrix component such as collagen and

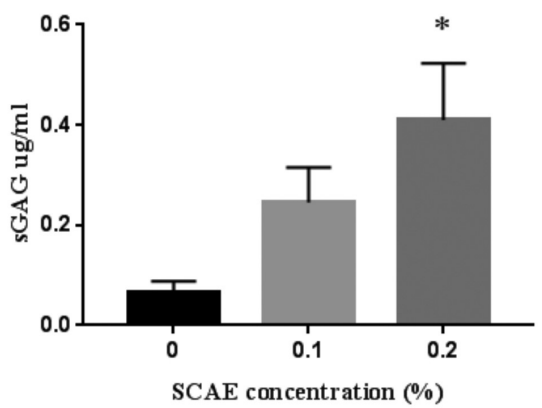

FIGURE 5. Sulphated glycosaminoglycan (sGAG) assay. sGAG production in human osteoarthritic chondrocytes in collagen type I hydrogel cultured for 7 days in FD with $0.1 \%$ and $0.2 \%$ SCAE supplementation compared with a control medium (FD only). A significantly higher expression of SGAG production was observed in the FD with $0.1 \%$ and $0.2 \%$ SCAE medium compared with the control medium after 7 days of culture: sGAG values was expressed as the mean $\pm \mathrm{SEM},(n=6)$ with $\# p<0.05$; compared values of control medium and FD with $0.1 \%$ SCAE, $* p<0.05$;

compared values of control medium and FD with $0.2 \%$

SCAE and $* * p<0.05$; compared values of FD with $0.1 \%$ SCAE and FD with $0.2 \%$ SCAE

elastic fibres were stained red-orange by eosin. In contrast to chondrocytes grown on the collagen hydrogel cultured in control medium, a significant increase in cell number was observed for chondrocytes at 7 days of cultured in 
the medium with SCAE supplementation, especially in the collagen hydrogel that cultured with $0.2 \%$ SCAE. Interestingly, most chondrocytes had merged to form large scaffold-adherent aggregates in the collagen hydrogel, which demonstrated higher cell density (Figure 6).

Toluidine blue staining confirmed the proteoglycans as well as glycosaminoglycans (sGAG) production in the collagen hydrogel cultured under medium with various concentration of SCAE supplementation (Figure 7). The collagen hydrogels cultured in medium supplemented with $0.1 \%$ and $0.2 \%$ SCAE demonstrated metachromatically stains with Toluidine blue for clusters of chondrocytes and their extracellular matrix, evidenced by a deep violet colour of matrix indicating large amounts of GAG accumulation in the matrix surrounding chondrocytes. The collagen hydrogel cultured in the control medium showed the least staining which appeared to be significantly different from the others. The result showed that the medium supplemented with SCAE is more favourable to chondrocytes production and deposition of GAG-containing proteoglycans in collagen hydrogel construct.

\section{DISCUSSION}

A natural component of connective tissue, collagen Type I has proven to be one of the most promising biomaterials because of its excellent biocompatibility and safe immunologically. It had been widely applied in tissue
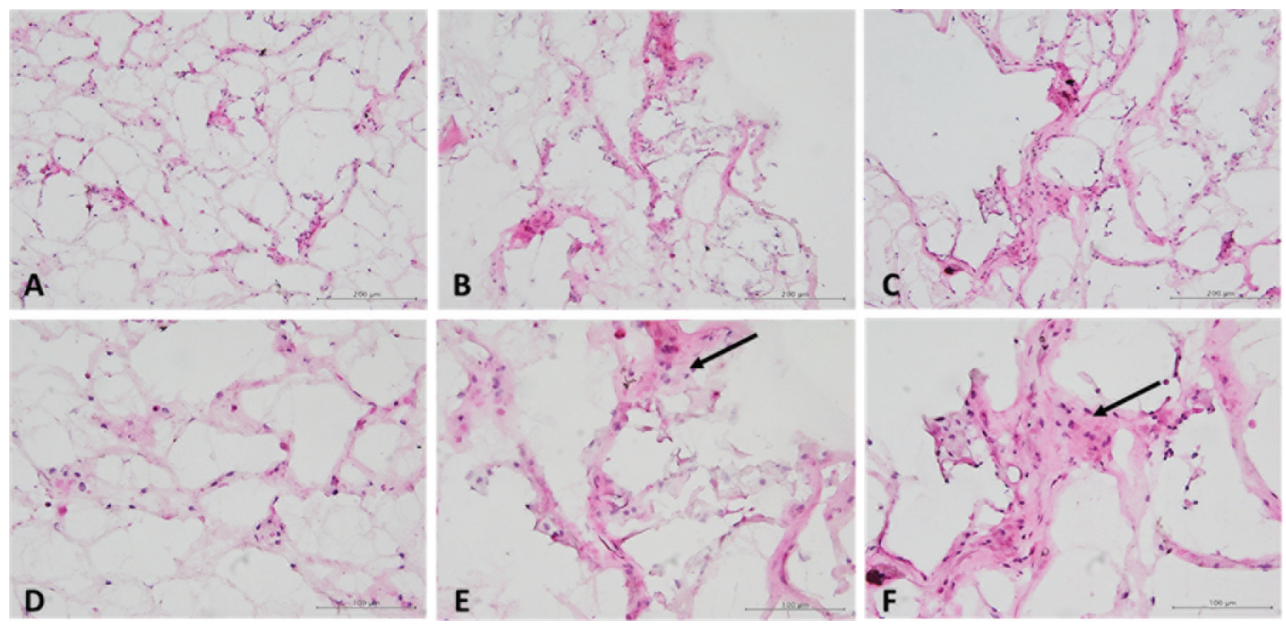

FIGURE 6. Haematoxylin and eosin staining of human OA chondrocytes in collagen type I hydrogel cultured for 7 days in a control medium (FD) (A), FD with $0.1 \%$ SCAE (B) and $0.2 \%$ SCAE (C) medium. Nuclei of chondrocytes were stained purplish blue by haematoxylin whereas extracellular matrix produced within the collagen hydrogel scaffold were stained red orange by eosin.

The cells were found loosely dispersed in the constructs and showed signs of lacunae and cartilage isolated cell.

Magnification 20× (Bars=100 $\mu \mathrm{m})$ and $40 \times($ Bars $=200 \mu \mathrm{m})$
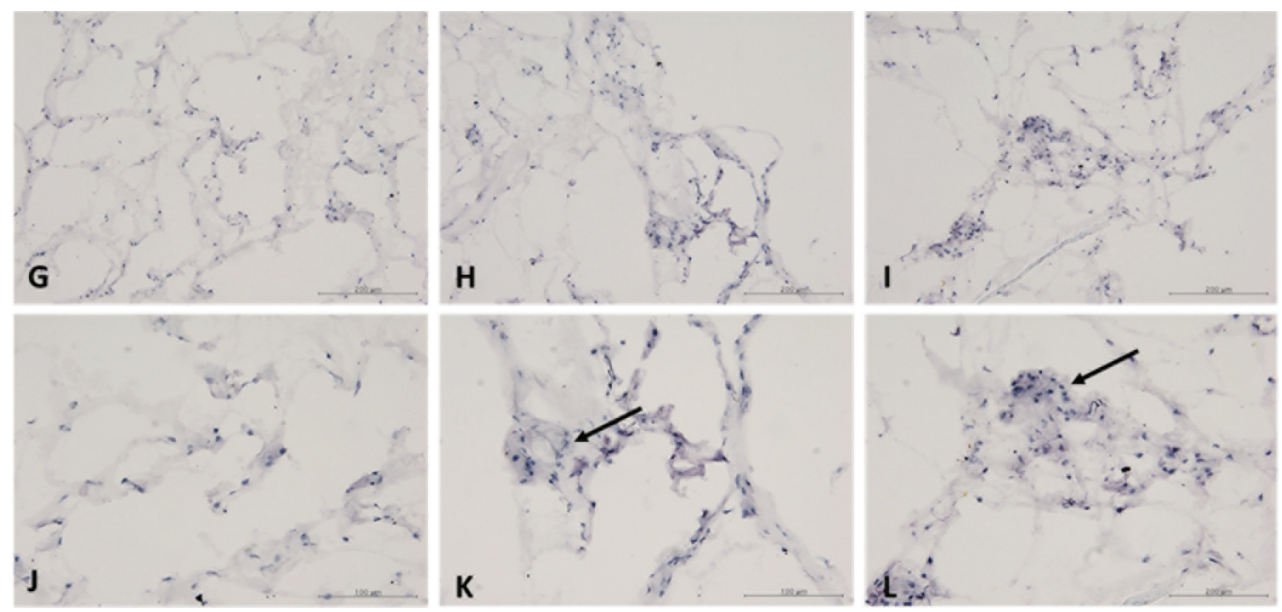

FIGURE 7. Toluidine blue staining of human OA chondrocytes in collagen type I hydrogel cultured for 7 days in a control medium

(FD) (A), FD with $0.1 \%$ SCAE (B) and $0.2 \%$ SCAE (C) medium. The clusters of chondrocytes and their extracellular matrix in collagen hydrogel cultured in FD with $0.1 \%$ and $0.2 \%$ SCAE supplementation were metachromatically stained with Toluidine blue, evidenced by a deep violet colour of matrix as compared to control medium which indicated a large amounts of GAG accumulation in the matrix surrounding chondrocytes. Magnification $20 \times($ Bars $=100 \mu \mathrm{m})$ and $40 \times(B a r s=200 \mu \mathrm{m})$ 
engineering, especially in hydrogel form. The collagen Type I hydrogel scaffolds can offer a three-dimensional surrounding for cells, similar to that of hyaline cartilage. The main function of cells is to synthesise and maintain the extracellular matrix. Once cells feel comfortable on scaffolds, they sense the environment and react accordingly. The elastic modulus of hydrogel affects the interstitial fluid flow which at last could influence the changes in cell phenotype and migration behaviour. In different case, elastic modulus and interstitial fluid flow can act alone or together and provide different findings such as in the case of cancer cell (Clay et al. 2016). It has been demonstrated that the cell seeding density is a positively correlated with extracellular matrix (Ren et al. 2016). The culture medium is another contributing factor in cellular metabolism and matrix synthesis. The proliferation of human OA chondrocytes in collagen hydrogel demonstrated increase in cell density in culture with medium containing SCAE. The chondrocytes are homogeneously distributed and redifferentiation inside the collagen hydrogel with good viability. The chondrocytes appeared polygonal rather than adopting spindle-like fibroblastic shape. These results indicate that the addition of SCAE to the medium favoured chondrocytes proliferation and phenotype maintenance in collagen hydrogel. The amino acid sequences in the collagen hydrogel may serve as binding sites for cell surface proteins, potentially leading to changes in the metabolic or proliferation response to the culture conditions tested in this study (Kisiday et al. 2005). Galois et al. (2006) tested the potentials of collagen type I as carriers for bovine articular chondrocytes, and found that collagen Type I hydrogel had promoted chondrocyte proliferation and was able to maintain an almost round morphology in culture. Three-dimensional culture can maintain the chondrocytes phenotype and the influence of SCAE in culture medium promotes cell growth, and prevents dedifferentiation as frequently seen in serum containing medium, which is ultimately helpful for the production of cartilage extracellular matrix (Mahapatra et al. 2016).

The major limitations for the use of cell-seeded collagen matrices for tissue engineering applications are the poor mechanical strength and the contraction of the matrices by the cells. The rate and extent of this contraction depend on the cell proliferation within the gel, collagen concentration, and the culture conditions (Yamaoka et al. 2005). Human OA chondrocytes in collagen type I hydrogel are contract and float with a rate of contraction related to cell density, in the culture medium with SCAE supplementation. Furthermore, collagen hydrogel with high chondrocyte density showed the highest gel contraction. However, there is possibility that the cell content in collagen hydrogel decreases with time to give a final cell density after gel contraction. The decrease in cell density during gel contraction may be due to cell apoptosis and migration out of the gel to the bottom of culture plate (Galois et al. 2006). Gel contraction could be beneficial for the production of cartilaginous constructs using chondrocytes due to the potential to increase the effective cell concentration.

A successful cartilage tissue engineering, chondrocytes must actively express all essential genes for the desired phenotype to generate a hyaline-like cartilage tissue with optimal biochemical and mechanical properties. A major problem in cell-based therapy of cartilage is the dedifferentiation of chondrocytes, which occurs during in vitro expansion. It is well known that during monolayer culture, chondrocytes lose their spherical shape and adopt to fibroblast-like morphology. This process is always accompanied by down-regulation of collagen Type II and aggrecan genes expressions, which are the main chondrogenic markers, and up-regulation of collagen Type I gene expression (Yamaoka et al. 2005). As a consequence of these previous results, the expression of genes encoding for collagen (Type I and II), sox9 and aggrecan core protein were tested to determine whether the collagen hydrogel incubated in medium with SCAE supplementation could maintain a chondrocyte-like phenotype.

In this study, human OA chondrocytes significantly expressed type II collagen and aggrecan core protein. The expression of gene encoding collagen type I and sox 9 were also detected, however, the expression was not significant where this phenomenon has been observed in previous studies (Galois et al. 2006; Yamaoka et al. 2005). The induction of redifferentiation by a medium containing SCAE, resulting slightly decreased the expression of collagen type I in collagen hydrogel, when compared with that in the control medium. Halbwirth et al. (2015) reported that the redifferentiation potential of OA chondrocytes in collagen type I hydrogel will be enhanced once under compressive mechanical loading stimulation where the chondrocytes redifferentiates from catabolic to anabolic phenotype. Thus, although the dedifferentiation was observed in vitro, the expression of chondrogenic markers would be restored after exposure to mechanical stimulation in vitro or implantation in vivo (Chung et al. 2008). As mentioned before, the dedifferentiation process of chondrocytes during monolayer causes down-regulation of chondrogenic markers. Interestingly, when the human OA chondrocyte were encapsulated in collagen type I hydrogel and cultured in the medium with SCAE, the expressions of collagen type II, sox 9 and aggrecan core protein were increased at a significant level with a similar pattern as previously shown for monolayer OA chondrocytes cultured in medium with the presence of SCAE. Comparison of the ratio of Col II/Col I mRNA levels confirms this result, demonstrating that under these conditions, dedifferentiation of the chondrocytes in the collagen hydrogel was lower than in monolayer culture. Tallheden et al. (2005) demonstrated that the OA chondrocyte in collagen type I hydrogel exhibited an increase in redifferentiation that occurred simultaneously with the increase in chondrocytes proliferation in 3-dimentional culture model. This recent study demonstrated that sox 9 and collagen type II were expressed lower than aggrecan 
core protein. During chondrogenesis, sox 9 is expressed in regions where deposition of cartilage matrix takes place and promotes expression of collagen type II which is an important structural component of cartilage (Melgarejo et al. 2014). The low expression of sox 9 may result in lower expression of collagen type II. However, other studies showed that the expression of sox 9 does not correlate with the expression of collagen type II in OA chondrocyte (Aigner et al. 2003). It seems therefore, reasonable to speculate that collagen type I hydrogel with the addition of SCAE is a convenient three-dimensional scaffold for the maintenance of a chondrocyte-like phenotype in vitro but the limited collagen type II synthesis needs to be addressed since it is important for the stability of the construct.

In tissue engineering, scaffolds should provide a platform that directs cell adhesion, proliferation, and extracellular matrix synthesis. The production of extracellular matrix proteins is very important for cartilage regeneration because chondrocytes in cartilage are surrounded by abundant extracellular matrix such as SGAG (Ledday et al. 2004). Ren at al. (2016) demonstrated that the extracellular matrix production was positively correlated with the total cell density and distribution pattern. The human OA chondrocytes in collagen hydrogel grown under the culture medium with various concentration of SCAE, showed a significant difference in the production of SGAG and toluidine blue staining. The OA chondrocytes in the collagen hydrogel, distributed throughout the network of the matrices separated from each other to lose avoid cellto-cell contacts and maintained spherical morphology. Some of the chondrocytes had merged to form large scaffold-adherent aggregates in the collagen hydrogel which demonstrated higher cell density. In contrast, the chondrocytes in conventional monolayer culture possess abundant cell-to-cell contacts and become dedifferentiated that the 3D environment promotes chondrocytes activity cannot be reproduced. This result indicated collagen type I hydrogel helps the chondrocytes in reducing cell to cell contacts and maintain the cell shape and function. The abundance of matrices metachromatically stained with toluidine blue for collagen type I hydrogel cultured in medium supplemented with SCAE, was consistent with the upregulation of the aggrecan core protein mRNA expression in which demonstrated the cellular aggregates were highly functional in producing proteoglycans, the major extracellular matrix molecules in cartilage, whereby the aggrecan accounts for $80 \%$ of total proteoglycans. Ledday et al. (2004) reported that the different trends in GAG production could be influenced by the culture type and scaffold material. Several studies using different materials for scaffold demonstrated that the chondrocytes release most of the GAG produced which was released into the culture medium (Xu et al. 2006). The quantification assays to confirm sGAG productions, result in a significant increase in GAG production that release into the medium for collagen hydrogel cultured in the medium with SCAE. These results suggested that collagen type I hydrogel can provide a biophysical and biochemical environment for chondrocytes to develop cartilage-like matrix during in vitro cultures. These properties with the addition of SCAE may promote the maintenance of the chondrocyte phenotype and enhance the expression and production of cartilaginous matrices, particularly proteoglycans, in the collagen type I hydrogel to some extent. Despite their potential, the collagen type I hydrogel lacks mechanical strength. Cross-disciplinary innovation enables the discovery of new methods to enhance the mechanical properties; thus, extending the application of these scaffolds. Most of the samples were limited and obtained from patients aged 68-70 years old. This may cause the chondrocytes' proliferation rates in the culture to be slow, resulting in differentiated cells. In order to overcome this, more chondrocytes should be obtained at the beginning of the culturing process.

\section{CONCLUSION}

The maintenance of phenotypically stable chondrocytes as well as maximising the extracellular matrix production in human OA chondrocytes is critical as autologous cell sourcing from a cartilage biopsy will remain as the most clinically relevant cell source currently due to the safety and regulatory concerns. This study demonstrated the potential of SCAE where the serum-free medium supplemented with 0.1 and $0.2 \%$ SCAE could stimulate chondrocyte proliferation, reduce dedifferentiation and increase cartilage matrix synthesis in collagen Type I hydrogel. The chondrocytes seeded in collagen Type I hydrogel and cultured under the serum-free medium supplemented with SCAE, could maintain their chondrocyte phenotype which may be beneficial for in vitro development of threedimensional chondrocytes culture for the use in cartilage tissue engineering therapies.

\section{ACKNOWLEDGEMENTS}

This study was made possible with financial support from Universiti Kebangsaan Malaysia (GUP-2013-23) and the Ministry of Education, Malaysia (ERGS/1/2012/SKK03/ $\mathrm{UKM} / 02 / 1)$. We thank the ethical committee for proposal approval and science officers in Tissue Engineering Centre at Universiti Kebangsaan Malaysia Medical Centre for technical assistance and expertise.

\section{REFERENCES}

Aigner, T., Gebhard, P.M., Schmid, E., Bau, B., Harley, V. \& Poschl, E. 2003. SOX9 expression does not correlate with type II collagen expression in adult articular chondrocytes. Matrix Biol. 22(4): 363-372.

Althunibat, O.Y., Ridzwan, B.H., Taher, M., Jamaludin, M.D., Ikeda, M.A. \& Zali, B.I. 2009. In vitro antioxidant and antiproliferative activities of three Malaysian sea cucumber species. Eur. J. Sci. Res. 37: 376-387.

Byers, B.A., Mauck, R.L., Chiang, I.E. \& Tuan, R.S. 2008. Transient exposure to transforming growth factor beta 3 under serum free conditions enhances the biomechanical and 
biochemical maturation of tissue-engineered cartilage. Tissue Engineering Part A 14: 11.

Callahan, L.A.S., Ganios, A.M., McBurney, D.L., Dilisio, M.F., Weiner, S.D., Horton Jr., W.E. \& Becker, M.L. 2012. ECM production of primary human and bovine chondrocytes in hybrid PEG hydrogels containing Type I collagen and hyaluronic acid. Biomacromolecules 13: 1625-1631.

Chen, G., Liu, D., Tadokoro, M., Hirochika, R., Ohgushi, H., Tanaka, J. \& Tateishi, T. 2004. Chondrogenic differentiation of human mesenchymal stem cells cultured in a cobweblike biodegradable scaffold. Biochemical and Biophysical Research Communications 322: 50-55.

Choo, P.S. 2008. Population status, fisheries and trade of sea cucumbers in Asia. Population status, fisheries and trade of sea cucumbers in Asia. FAO Fisheries and Aquaculture Technical 516: 81-118.

Chowdhury, S.R., Mohd Fauzi, M.B., Lokanathan, Y., Min, H.N., Jia X.L., Ude, C.C. \& Ruszymah, B.H.I. 2018. Collagen Type I: A versatile biomaterial. Adv. Exp. Med. Biol. 1077: 389-414.

Chung, C., Erickson, I.E., Mauck, R.L. \& Burdick, J.A. 2008. Differential behavior of auricular and articular chondrocytes in hyaluronic acid hydrogels. Tissue Engineering Part A 14(7): 1121-1131.

Clay, N.E., Shin, K., Ozcelikkale, A., LeE, M.K., Rich, M.H., Kim, D.H., Han, B. \& Kong, H. 2016. Modulation of matrix softness and interstitial flow for $3 \mathrm{D}$ cell culture using a cell-microenvironment-on-a-chip (C-MOC) system. ACS Biomater. Sci. Eng. 2(11): 1968-1975.

Drury, J.L. \& Mooney, D.J. 2003. Hydrogels for tissue engineering: Scaffold design variables and applications. Biomaterials 24: 4337-4351.

Fauzi, M.B., Lokanathan, Y., Aminuddin, B.S., Ruszymah, B.H.I. \& Chowdhury, S.R. 2016. Ovine tendon collagen: Extraction, characterisation and fabrication of thin films for tissue engineering applications. Materials Science and Engineering C 68: 163-171.

Fredalina, B.D., Ridzwan, B.H., Abidin, A.A., Kaswandi, M.A., Zaiton, H., Zali, I., Kittakoop, P. \& Jais, A.M. 1999. Fatty acid compositions in local sea cucumber, Stichopus chloronotus, for wound healing. Gen. Pharmacol. 33: 337-340.

Forbes, R., IIias, Z., Baine, M., Choo, P.S. \& Wallbank, A. 1999. A taxonomic key and field guide to the sea cucumbers of Malaysia. Heriot -Watt University.

Galois, L., Hutasse, S., Cortial, D., Rousseau, C.F., Grossin, L., Ronziere, M.C., Herbage, D. \& Freyria, A.M. 2006. Bovine chondrocyte behaviour in three-dimensional Type I collagen gel in terms of gel contraction, proliferation and gene expression. Biomaterials 27: 79-90.

Halbwirth, F., Niculescu-Morzsa, E., Zwickl, H., Bauer, C. \& Nehrer, S. 2015. Mechanostimulation changes the catabolic phenotype of human dedifferentiated osteoarthritic chondrocytes. Knee Surg. Sports Traumatol. Arthrosc. 23(1): 104-111.

Jeyakumar, V., Halbwirt, F., Niculescu-Morzsa, E., Bauer, C., Zwickl, H., Kern, D. \& Nehrer, S. 2016. Chondrogenic gene expression differences between chondrocytes from osteoarthritic and non-OA trauma joints in a 3D collagen Type I hydrogel. Cartilage 8(2): 191-198.

Kisiday, J.D., Kurz, B., Dimicco, M.A. \& Grodzinsky, A.J. 2005. Evaluation of medium supplemented with insulintransferrin-selenium for culture of primary bovine calf chondrocytes in three-dimensional hydrogel scaffolds tissue engineering. Tissue Eng. 11(1-2): 141-151.
Klein, T.J., Rizzi, S.C., Schrobback, K., Reichert, J.C., Jeon, J.E., Crawford, R.W. \& Hutmacher, D.W. 2010. Long-term effects of hydrogel properties on human chondrocyte behavior. The Royal Society of Chemistry 6: 5175-5183.

Kontturi, L.S., Järvinen, E., Muhonen, V., Collin, E.C., Pandit, A.S., Kiviranta, I., Yliperttula, M. \& Urtti, A. 2014. An injectable, in situ forming Type II collagen/hyaluronic acid hydrogel vehicle for chondrocyte delivery in cartilage tissue engineering. Drug Deliv. and Transl. Res. 4(2): 149-158.

Ledday, H.A., Awad, H.A. \& Guilak, F. 2004. Molecular diffusion in tissue engineered cartilage constructs: Effects of scaffold material, time and culture conditions. J. Biomed. Mater. Res. 70B: 397-406.

Levett, P.A., Melchels, F.P.W., Schrobback, K., Hutmacher, D.W., Malda, J. \& Klein, T.J. 2013. Chondrocyte redifferentiation and construct mechanical property development in singlecomponent photocrosslinkable hydrogels. Journal of Biomedical Materials Research A 102(8): 2544-2553.

Mahapatra, C., Jin, G.Z. \& Kim, H.W. 2016. Alginate-hyaluronic acid-collagen composite hydrogel favorable for the culture of chondrocytes and their phenotype maintenance. Tissue Eng. Regen. Med. 13(5): 538-546.

Melgarejo, R.Y., Sanchez, S.R., Garcia, C.Z., Garcia, L.J., Gutierrez, G.C., Luna, B.G., Ibarra, C. \& Velasquillo, C. 2014. Biocompatibility of human auricular chondrocytes cultured onto a chitosan/polyvynil alcohol/epichlorohydrinbased hydrogel for tissue engineering application. Int. J. Morphol. 32(4): 1347- 1356.

Mohd Yunus Mohd Heikal, Shuid Ahmad Nazrun, Kien Hui Chua \& Abd Ghafar Norzana. 2019. Stichopus chloronotus aqueous extract as a chondroprotective agent for human chondrocytes isolated from osteoarthitis articular cartilage in vitro. Cytotechnology 71(2): 521-537. https://doi.org/10.1007/ s10616-019-00298-2.

Nurzazlin, B.Z.N., Shamsul, B.S., Yahya, N.H.M., Ruszymah, B.H.I., Abdul Rani, R. \& Chowdhury, S.R. 2018. Comparative study on cartilage tissue collected from less- and severelyaffected region of osteoarthritic knee. Med. \& Health 13(1): 77-87.

Park, J.S., Yang, H.N., Woo, D.G., Jeon, S.Y. \& Park, K.H. 2011 Chondrogenesis of human mesenchymal stem cells in fibrin constructs evaluated in vitro and in nude mouse and rabbit defects models. Biomaterials 32: 1495-1507.

Ren, X., Wang, F., Chen, C., Gong, X., Yin, L. \& Yang, L. 2016. Engineering zonal cartilage through bioprinting collagen Type II hydrogel constructs with biomimetic chondrocyte density gradient. BMC Musculoskeletal Disorders 17: 301.

Tallheden, T., Bengtsson, C., Brantsing, C., Sjogren-Jansson, E., Carlsson, L., Peterson, L., Brittberg, M. \& Lindahl, A. 2005. Proliferation and differentiation potential of chondrocytes from osteoarthritic patients. Arthritis Res. Ther. 7(3): R560-R568.

Xu, X., Urban, J.P.G., Tirlapur, U., Wu, M.H., Cui, Z. \& Cui, Z. 2006. Influence of perfusion on metabolism and matrix production by bovine articular chondrocytes in hydrogel scaffolds. Biotechnology and Bioengineering 93(6): 11031111.

Yamaoka, H., Asato, H., Ogasawara, T., Nishizawa, S., Takahashi, T., Nakatsuka, T., Koshima, I., Nakamura, K., Kawaguchi, H., Chung, U., Takato, T. \& Hoshi, K. 2005. Cartilage tissue engineering using human auricular chondrocytes embedded in different hydrogel materials. Journal of Biomedical Materials Research Part A 78(1): 1-11. 
Yan, C. \& Pochan, D.J. 2010. Rheological properties of peptidebased hydrogels for biomedical and other applications. Chemical Society Reviews 39(9): 3528-3540.

Zhang, L., Song, H. \& Zhao, X. 2009. Optimum combination of insulin-transferrin-selenium and fetal bovine serum for culture of rabbit articular chondrocytes in three dimensional alginate scaffolds. International Journal of Cell Biology 2009: 747016

Mohd Heikal Mohd Yunus* \& Chua Kien Hui Department of Physiology, Faculty of Medicine Universiti Kebangsaan Malaysia

Jalan Yaacob Latif, Bandar Tun Razak 56000 Cheras, Kuala Lumpur, Federal Territory Malaysia

Ahmad Nazrun Shuid

Department of Pharmacology, Faculty of Medicine Universiti Kebangsaan Malaysia

Jalan Yaacob Latif, Bandar Tun Razak

56000 Cheras, Kuala Lumpur, Federal Territory

Malaysia

Norzana Abdul Ghafar Department of Anatomy Universiti Kebangsaan Malaysia Medical Centre Jalan Yaacob Latiff, Bandar Tun Razak 56000 Cheras, Kuala Lumpur, Federal Territory Malaysia
Mohd Heikal Mohd Yunus* \& Mohd Fauzi Busra Tissue Engineering Centre

Universiti Kebangsaan Malaysia Medical Center Jalan Yaacob Latif, Bandar Tun Razak 56000 Cheras Kuala Lumpur, Federal Territory Malaysia

Rizal Abd Rani

Department of Orthopaedic

Universiti Kebangsaan Malaysia Medical Center

Jalan Yaacob Latif, Bandar Tun Razak

56000 Cheras Kuala Lumpur, Kuala Lumpur, Federal Territory Malaysia

*Corresponding author; email: mohdheikalyunus@yahoo.com

Received: 25 September 2018

Accepted: 6 May 2019 